\title{
Characterisation of physiological and immunological differences between Pacific oysters (Crassostrea gigas) genetically selected for high or low survival to summer mortalities and fed different rations under controlled conditions
}

\author{
Maryse Delaporte ${ }^{\mathrm{a}}$, Philippe Soudant ${ }^{\mathrm{b},{ }^{*}}$, Christophe Lambert ${ }^{\mathrm{b}}$, Marine Jegaden $^{\mathrm{b}}$, Jeanne \\ Moal $^{\mathrm{a}}$, Stéphane Pouvreau ${ }^{\mathrm{a}}$, Lionel Dégremont ${ }^{\mathrm{c}}$, Pierre Boudry ${ }^{\mathrm{c}}$, Jean-François Samain ${ }^{\mathrm{a}}$
}

\begin{abstract}
'Laboratoire de Physiologie des Invertébrés, centre IFREMER de Brest, BP 70, 29280 Plouzané, France.
baboratoire des Sciences de l'Environnement Marin, UMR 6539, Institut Universitaire Européen de la Mer, Université de Bretagne Occidentale, Place Copernic,Technopôle Brest-Iroise, 29280 Plouzané, France.

'Laboratoire de Génétique et Pathologie, IFREMER,17390 La Tremblade, France.

*: Corresponding author : P. Soudant, phone: + 33 (0) 2984986 23, fax.: + 33 (0) 29849

1686 45, email address : Philippe.Soudant@univ-brest.fr
\end{abstract}

\begin{abstract}
:
Within the framework of a national scientific program named "MORtalités ESTivales de l'huitre creuse Crassostrea gigas" (MOREST), a family-based experiment was developed to study the genetic basis of resistance to summer mortality in the Pacific oyster, Crassostrea gigas. As part of the MOREST project, the second generation of three resistant families and two susceptible families were chosen and pooled into two respective groups: "R" and "S". These two groups of oysters were conditioned for 6 months on two food levels (4\% and $12 \%$ of oyster soft-tissue dry weight in algal dry weight per day) with a temperature gradient that mimicked the Marennes-Oléron natural cycle during the oyster reproductive period. Oyster mortality remained low for the first two months, but then rapidly increased in July when seawater temperature reached $19{ }^{\circ} \mathrm{C}$ and above. Mortality was higher in "S" oysters than in "R" oysters, and also higher in oysters fed the $12 \%$ diet than those fed $4 \%$, resulting in a decreasing, relative order in cumulative mortality as follows; $12 \%$ " $S$ " > 12\% "R" > 4\% "S" > 4\% "R". Although the observed mortality rates were lower than those previously observed in the field, the mortality differential between "R" and "S" oysters was similar. Gonadal development, estimated by tissue lipid content, followed a relative order yielding a direct, positive relationship between reproductive effort and mortality as we reported precedently by quantitative histology. Regarding hemocyte parameters, one of the most striking observations was that reactive oxygen species (ROS) production was significantly higher in "S" oysters than in "R" oysters in May and June, regardless of food level. The absence of known environmental stress under these experimental conditions suggests that the ROS increase in "S" oyster could be related to their higher reproductive activity. Finally, a higher increase in hyalinocyte counts was observed for"S" oysters, compared to "R" oysters, in July, just before mortality. Taken together, our results suggest an association of genetically based resistance to summer mortality, reproductive strategy and hemocyte parameters.
\end{abstract}

Keywords: Crassostrea gigas; Genetic selection; Hemocyte parameters; Reactive oxygen species (ROS); Reproduction; Summer mortality 


\section{Introduction}

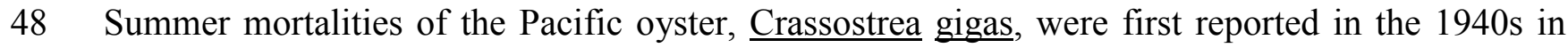

49 Japan (Koganezawa, 1974), in the late 1950s on west coast of North America (Glude, 1974;

50 Koganezawa, 1974; Cheney et al., 2000), and in early 1980s in France (Goulletquer et al., 1998).

51 These seasonal mortalities affect both adults and juveniles, with no specific clinical signs of

52 disease.

53 To date, some pathogenic agents have been detected and isolated during summer-mortality events

54 (Elston et al., 1987; Friedman and Hedrick, 1991; Lacoste et al., 2001; Le Roux et al., 2002;

55 Waechter et al., 2002; Gay et al., 2004; Garnier et al., in press), but these organisms have not

56 been clearly and systematically implicated in mortalities. One common feature of these summer-

57 mortality events is that they are associated with at least one of the following parameters: high

58 trophic conditions, elevated summer temperatures, and coincidence with the period of sexual

59 ripeness in oysters (Soletchnik et al., 1999; Soletchnik et al., 2003; Soletchnik et al., 2005). Only

60 a few experimental studies, however, have confirmed this contention (Lipovsky and Chew, 1972;

61 Perdue et al., 1981). The high energetic cost associated with reproduction, combined with high

62 summer temperatures, was hypothesized to weaken the oysters and make them more susceptible

63 to opportunistic pathogens (Perdue et al, 1981, Koganezawa, 1974). Findings from MOREST, a

64 national multidisciplinary program initiated in France in 2001, show that other environmental and

65 potentially-stressful factors associated with rain, aquaculture practices, and sediment quality also

66 seemed to be related to oyster summer mortality (Soletchnik et al., 2003; Soletchnik et al., 2005).

67 Moreover, summer mortality was found to be linked, to some extent, to genetic variability in

68 oysters (Beattie et al., 1980; Hershberger et al., 1984; Ernande et al., 2004). During the MOREST

69 project, bi-parental families were bred in the hatchery following a half-sib nested design and

70 deployed in three rearing sites (Ronce, Rivière d'Auray and Baie des Veys) during the summer 
71 2001. At the end of the summer period, family had the largest variance-component for survival 72 (46\%) (Dégremont et al., 2005). Heritability of spat survival was estimated to be very high 73 (Dégremont et al., 2007). In 2002, families selected for high (called "R" for resistant) or low 74 ("S" for susceptible) survival were used to produce a second generation which tested in the field under similar conditions as the previous year In October, the mortality of the "R" oysters was $2 \%$, $12 \%$ and $6 \%$ in Ronce, Rivière d'Auray, and Baie des Veys sites, respectively, but consistently higher, $23 \%, 42 \%$ and $32 \%$ for the "S" oysters. Once again, second generation family represented the largest variance $(61 \%)$, and this second field experiment confirmed that survival is a highly heritable trait (Dégremont, 2003). Other family-based, selective-breeding programs also have shown high broad-sense heritability for survival in C. gigas (Evans and Langdon, 2006) and $C$. virginica (Dégremont, personal communication) and realized heritability for yield, a parameter

82 combining survival and growth, in C. gigas on the US West Coast (Langdon et al., 2003). Clearly

83 a significant genetic effect was observed in the complex summer mortality phenomenon.

84 Little information is available, however, on the physiological basis of divergent selection for "S" vs "R" oysters. Within the framework of MOREST, several field and laboratory studies were performed to compare various biological parameters in " $\mathrm{R}$ " and "S" oyster families, or groups of

87 families, to explain survival differences (Samain et al., in press). As mentioned before, the high energetic cost associated with reproduction, combined with high summer temperatures and other

89 possible stresses, is suspected to weaken the oysters and make them more susceptible to 90 opportunistic pathogens. As capability of an oyster to react to diseases, injuries or parasite 91 infestation depends upon innate, humoral and cellular defence mechanisms (Cheng, 2000; Chu, 92 2000), it appears pertinent to assess whether or not survival traits include better immune 93 responses. 
95 One approach to assessing immune responses of oysters is to measure hemocyte parameters

96 (descriptive and functional). Indeed, hemocytes are considered to be the main cellular mediators

97 of the defence system in bivalves (Volety and Chu, 1995; Cheng, 1996), responsible for

98 recognition, phagocytosis, and elimination of non-self particles by microbicidal activities (Pipe,

99 1992; Cheng, 2000; Chu, 2000). Recently, we reported that some hemocyte activities

100 (phagocytosis, adhesion) decreased during gametogenesis, especially when gonads approach

101 ripeness (Delaporte et al., 2006a; Gagnaire et al., 2006). Other studies (Enriquez-Diaz, 2004)

102 demonstrated by histological analysis that "S" families from the first generation exhibited earlier

103 and higher gonad development than " $R$ " families when reared together in Rivière d'Auray

104 (France).

105 In the present study, the objective was to assess whether or not different survival of summer

106 mortalities is related to reproductive, energetic, or immune status evaluated by quantifying

107 biochemical and hemocyte parameters. These parameters were assessed on a subsample of

108 animals from a group of three "R" families and a group of two "S" families produced by

109 divergent selection and evaluated in the field, as reported above. These groups were compared in

110 experimental conditions during the period of active reproduction (from April to August 2003). To

111 exacerbate any putative difference in reproductive strategy between " $R$ " and "S" oysters, and thus

112 assess interactions between reproduction and survival phenotype, oysters of both " $\mathrm{R}$ " and " $\mathrm{S}$ "

113 groups were fed two levels of food ( $4 \%$ and $12 \%$ of oyster dry weight in algal dry weight per

114 day).

115

116

117

\section{2. Materials and Methods}


121 Second generation (G2) of summer mortality-susceptible " $\mathrm{S}$ " and -resistant "R" oyster families 122 were produced in 2002 in the IFREMER hatchery at La Tremblade (Charente, France) from

123 broodstocks selected based upon the survival phenotype in 2001 (Dégremont et al., 2003). From

124 each selected F1 family, 25 females and 25 males were used as parents to produce a F2 family.

125 Spat of G2 "S" and "R" families were reared at the IFREMER station in Bouin (Vendée, France),

126 a cold-water site, to prevent summer mortality, and then kept in a commercial hatchery in

127 Normandy (France) during the winter period of 2002-2003. In March 2003, one-year-old oysters

128 from three second generation resistant families and two second generation susceptible families

129 were combined to constitute one stock of resistant oysters and one of susceptible oysters. Each

130 stock was separated in two 700 -L raceways to be fed $4 \%$ and $12 \%$ of oyster dry weight in algal

131 dry weight per day (termed as 4\% and 12\% diets) from April to August 2003 at the IFREMER

132 experimental hatchery in Argenton (Finistère, France). The algal diet consisted of a mixture of

133 four micro-algae: T-Iso (Isochrysis affinis galbana, clone Tahiti), Chaetoceros calcitrans,

134 Skeletonema costatum and Tetraselmis chui provided in equal biomass proportions. During the

135 dietary conditioning, the annual average of photoperiod and temperature cycle of Marennes-

136 Oléron was applied, as described by Delaporte et al. (2006a). Tanks and oysters were cleaned

137 daily, and oyster mortality was monitored. Each month from April to August, ten oysters were 138 sampled from each group to analyse the biochemical and hemocyte parameters.

140 2.2. Biochemical parameters and condition index

141 Each month, shell weight and flesh wet weight of 10 oysters were measured after widthdrawal of 142 hemolymph for hemocyte parameter analysis described below. Individual animals were frozen in 
143 liquid nitrogen $\left(-196^{\circ} \mathrm{C}\right)$ and ground with a Dangoumeau homogeniser; the resulting homogenate

144 was stored at $-80^{\circ} \mathrm{C}$ for latter biochemical analysis. To assess whole, oyster-flesh dry weight, a

145 known amount of the above homogenate was weighed in a pre-weighed aluminium cup, dried for

$14648 \mathrm{~h}$ at $80^{\circ} \mathrm{C}$ and then weighed again. A dry weight / wet weight ratio was estimated from these

147 measurements and used to back-calculate individual whole, oyster-flesh dry weight. Condition

148 index of individual oysters was then calculated as described previously (Walne and Mann, 1975),

149 following the formula: dry flesh weight / dry shell weight X 1000.

150

151 Biochemical analyses on homogenates (stored at $-80^{\circ} \mathrm{C}$ ) of 10 individual oysters were performed 152 as previously described (Delaporte et al., 2006a). Total lipid content was estimated according to

153 (Bligh and Dyer, 1959) and carbohydrate content was measured colorimetrically (Dubois et al., 154 1956). Carbohydrate and lipid contents were expressed as mg of lipid or carbohydrate per mg of 155 oyster dry weight.

\section{2.3. Measurements of hemocyte parameters by flow cytometry}

158 Characterisation of hemocyte sub-populations, number and functions were performed using a 159 FACScalibur (BD Biosciences, San Jose, CA USA) flow cytometer equipped with a $488 \mathrm{~nm}$ 160 argon laser. As recommended by FCM manufacturer, all samples were filtered through $80 \mu \mathrm{m}$ 161 mesh prior to analysis to eliminate any large debris $(>80 \mu \mathrm{m})$ which could potentially clog the 162 flow cytometer. Methods for measuring hemocyte parameters are described hereafter.

164 2.3.1. Hemolymph sampling

165 Hemolymph was withdrawn from individual oysters using a $1 \mathrm{ml}$ plastic syringe fitted with a 25166 gauge needle inserted through a notch made adjacent to the adductor muscle just prior to 
167 bleeding. All hemolymph samples were examined microscopically to check for contamination

168 (e.g., gametes, tissue debris) and then stored in micro-tubes held on ice.

169 Two kinds of hemocyte parameters were evaluated on hemolymph: descriptive parameters

170 (hemocyte viability and total and hemocyte sub-population concentrations), and functional ones

171 (phagocytosis, adhesion assay and reactive oxygen species (ROS) production). Analyses were

172 done as described below.

173

174 2.3.2. Descriptive parameters: Hemocyte viability, total and hemocyte sub-population

175 concentration

176 These parameters were measured individually on 10 hemolymph samples, for each sampling date

177 and each condition (4 and $12 \%$ diet, $\mathrm{R}$ and $\mathrm{S}$ ). An aliquot of $100 \mu 1$ of individual hemolymph was

178 transferred into a tube containing a mixture of Anti-Aggregant Solution for Hemocytes, AASH

179 (Auffret and Oubella, 1995) and filtered sterile seawater (FSSW), $200 \mu 1$ and $100 \mu 1$ respectively.

180 Hemocyte DNA was stained with two fluorescent DNA/RNA specific dyes, SYBR Green I

181 (Molecular probes, Eugene, Oregon, USA, 1/1000 of the DMSO commercial solution), and

182 propidium iodide (PI, Sigma, St Quentin Fallavier, France, final concentration of $10 \mu \mathrm{g} \mathrm{ml} \mathrm{l}^{-1}$ ) in

183 the dark at room temperature $\left(20^{\circ} \mathrm{C}\right)$ for 60 minutes before flow-cytometric analysis. SYBR

184 Green I permeates both dead and live cells, while PI permeates only through membranes of dead

185 cells. SYBR Green and PI fluorescences were measured at 500-530 nm (green) and at 550-600

$186 \mathrm{~nm}$ (red), respectively, by flow-cytometry. Thus, by counting the cells stained by PI and cells

187 stained by SYBR Green, it was possible to estimate the percentage of viable cells in each sample.

188 All SYBR Green-stained cells were visualised on a Forward Scatter height (FSC, size) and Side

189 Scatter height (SSC, cell complexity) cytogram, allowing identification of hemocyte sub190 populations. Granulocytes are characterised by high FSC and high SSC, hyalinocytes by high 
191 FSC and low SSC, while small agranulocytes have low FSC and SSC. Thus, the three sub-

192 populations were distinguished according to their size and cell complexity (granularity). Total

193 hemocyte, granulocyte, hyalinocyte, and small agranulocyte concentrations estimated from the

194 flow rate measurement of the flow-cytometer (Marie et al., 1999) as all samples were run for 30

195 sec. Results were expressed as number of cells per ml. Small agranulocyte concentrations are not

196 presented in this report because they represented only a small proportion of the total hemocyte

197 count and are considered to possess little activity (Lambert et al., 2003).

199 2.3.3. Functionnal parameters

200 These parameters were measured on pool of hemolymph. For each sampling date and each 201 condition (4 and 12\% diet, "R" and "S"), hemolymph from at least five animals was pooled and 202 analyses were ran on three pools of five individuals.

204 2.3.3.1. Phagocytosis

205 An aliquot of $100 \mu \mathrm{L}$ pooled hemolymph, diluted with $100 \mu \mathrm{L}$ of FSSW, was mixed with $30 \mu \mathrm{L}$ 206 of YG, 2.0- $\mu \mathrm{m}$ fluoresbrite microspheres, diluted to 2\% in FSSW (Polysciences, Eppelheim, 207 Germany). After 120 minutes of incubation at $18^{\circ} \mathrm{C}$, hemocytes were fixed with $230 \mu \mathrm{L}$ of a $6 \%$ 208 formalin solution and analysed at 500-530 nm by flow cytometry to detect hemocytes containing

209 fluorescent beads. The percentage of phagocytic cells was defined as the percentage of hemocytes 210 that had engulfed three or more beads (Delaporte et al., 2003). 
214 Hemocyte adhesion assays were performed according to the procedure reported previously

215 (Delaporte et al., 2006a), adapted from another study (Choquet et al., 2003). Briefly, a 100 $\mu \mathrm{L}$

216 aliquot of pooled hemolymph was allowed to adhere in an 24-well microplate, either in sterile

217 seawater or in seawater with Vibrio sp. S322 (50 bacteria/ hemocyte), a strain known for its

218 pathogenecity to bivalve larvae (Nicolas et al., 1996). After three hours of incubation, non-

219 adhering cells were fixed in 6\% formalin solution and stained using SYBR Green I (final

220 concentration, 1/1,000 in DMSO) and then detected and counted by flow-cytometry. Results are

221 expressed as the percentage of adhering hemocytes incubated with FSSW or bacteria, relative to

222 the initial hemocyte count.

223

224 2.3.3.3. Reactive oxygen species production

225 Reactive oxygen species (ROS) production by untreated hemocytes was measured using 2'7'-

226 dichlorofluorescein diacetate, DCFH-DA (Lambert et al., 2003). A $100 \mu \mathrm{L}$ aliquot of pooled

227 hemolymph was diluted with $300 \mu \mathrm{l}$ of FSSW. Four $\mu \mathrm{L}$ of the DCFH-DA solution (final 228 concentration of $0.01 \mathrm{mM}$ ) was added to each tube maintained on ice. Tubes were then incubated

229 at $18^{\circ} \mathrm{C}$ for 120 minutes. After the incubation period, DCF fluorescence, quantitatively related to 230 the ROS production of untreated hemocytes, was measured at 500-530 $\mathrm{nm}$ by flow-cytometry.

231 Results are expressed as the mean geometric fluorescence (in arbitrary units, AU) detected in 232 each hemocyte sub-population.

233

\section{$234 \quad$ 2.4. Statistical analysis}

235 Three-way, multifactor analysis of variance was performed to compare biochemical and 236 hemocyte parameters (independent variables) according to diet, phenotype (summer mortality 237 susceptible and resistant oysters), and sampling date. Percentage data were transformed (as 
238 arcsine of the square root) before MANOVA, but are presented in figures and tables as

239 untransformed percentages. The method used to discriminate between the means was Fisher's

240 least significant difference (LSD) procedure. Results were deemed significant at $\mathrm{p}<0.05$. All

241 statistical analyses were performed using STATGRAPHICS Plus 5.1 (Manugistics, Rockville, 242 USA).

\section{3. Results}

245 All statistical analyses are summarized in Table 1. Immediately apparent is a significant 246 difference between " $\mathrm{R}$ " and "S" oyster phenotypes, for biochemical parameters (carbohydrate 247 and lipid contents) and for hemocyte parameters (hyalinocyte counts and ROS production of 248 hyalinocytes and granulocytes). Details are presented below.

\subsection{Oyster mortality}

251 Cumulative mortality was monitored throughout the experiment. Cumulative mortality remained 252 below 5\% during the first two months. A rapid increase in mortality was noticed in July, up to a 253 maximum of 19\% (Figure 1), resulting in differences in cumulative mortality according to dietary 254 treatment and oyster phenotype. Oysters fed the 12\% diet exhibited higher mortalities than those 255 fed the $4 \%$ diet, while "S" oysters showed higher mortalities than "R" oysters. Consequently, a 256 gradient in oyster cumulative mortality was observed as follows: $12 \%$ " $\mathrm{S}$ " oysters $>12 \%$ " $\mathrm{R}$ " 257 oysters $>4 \%$ "S" oysters $>4 \%$ "R" oysters, from July until the end of the experiment. 
261 Condition index was significantly affected by food level (Figure 2, MANOVA, p<0.0001), but

262 not by oyster phenotype or sampling date. Oysters fed the $12 \%$ diet had a higher mean condition 263 index than those fed the $4 \%$ diet. However, it should be noted that condition index of summer

264 mortality-susceptible oysters fed the $12 \%$ diet dropped significantly (only in July) compared to 265 corresponding, resistant oysters. This selective drop in condition index resulted in significant 266 interactions between time and diet $(\mathrm{P}<0.05)$ and between time and phenotype $(\mathrm{P}<0.01)$.

\subsection{Biochemical composition}

269 Carbohydrate content of oysters was significantly affected by oyster phenotype (Figure 3A, $\mathrm{p}<0.05$ ), with " $\mathrm{S}$ " oyster families having a higher mean carbohydrate content compared to " $\mathrm{R}$ " oysters. Also, a significantly-higher carbohydrate content was reported in oysters fed the $12 \%$

272 diet, compared to oysters fed the $4 \%$ diet $(p<0.05)$. Carbohydrate content was also greatly 273 affected by sampling date $(\mathrm{p}<0.0001)$, decreasing steadily from May to August. Finally, a 274 significant interaction was noted between diet and time.

275 A significantly-higher mean lipid content was observed in "S" oysters compared to "R" oysters 276 (Figure 3B, $\mathrm{p}<0.01$ ). Total lipid content was also significantly affected by the dietary conditioning $(\mathrm{p}<0.0001)$. Oysters fed the $12 \%$ diet contained a higher lipid content than those fed the $4 \%$ diet. As with carbohydrate content, total lipid content changed significantly over time

$279(\mathrm{p}<0.05)$; total lipid content increased during the course of the experiment. Note, however, that 280 lipid content of "S" oysters fed both 4 and 12\% diets dropped temporarily in July, but this drop in 281 lipid occurred one month later for " $\mathrm{R}$ " oysters. Interaction between time and phenotype was the 282 only significant interaction for the lipid content and was likely attributable to this drop in July for 283 the "S" oyster families. 


\subsection{Hemocyte viability}

286 No significant difference was observed between dietary treatments, nor between summer 287 mortality-susceptible and -resistant oyster families. Percentages of alive hemocytes ranged from $28895.8 \%$ to $99 \%$ during the course of the experiment (data not shown).

\subsection{Total hemocyte, granulocyte and hyalinocyte concentrations}

291 As total hemocyte concentration was mostly represented by hyalinocytes and granulocytes, only

292 changes in these hemocyte sub-population concentrations of " $\mathrm{R}$ " and " $\mathrm{S}$ " oysters fed the two

293 dietary conditionings are detailed below.

294 Counts of hyalinocytes, which represented the predominant hemocyte sub-population, were 295 significantly different in the two oyster phenotypes (Figure 4B, p $>0.05$ ) and were affected by 296 dietary conditioning as well (Table $1, \mathrm{p}<0.0001)$. Granulocyte counts were not affected by either

297 factor (diet or oyster phenotype). During the entire experiment, "S" oysters contained more 298 circulating hyalinocytes than "R" oysters, especially in July. Feeding oysters the $12 \%$ diet 299 resulted in a higher hyalinocyte count than in oysters fed the $4 \%$ diet (Table 1). Neither oyster 300 phenotype nor dietary treatment affected total hemocyte or granulocyte concentrations. The most 301 significant changes in total hemocyte, hyalinocyte and granulocyte counts were related to the 302 sampling date; mainly there was an appreciable increase in both cell types in July.

\section{3.7. Phagocytosis}

305 Results showed that neither phenotype nor dietary effects were observed (Table 1). Phagocytosis 306 varied significantly between sampling dates (Figure 5) with the lowest phagocytic activity in May 307 and the highest in June $(\mathrm{p}<0.0001)$. 


\subsection{Adhesion capacity}

310 As with hemocyte phagocytic activity, neither phenotype nor diet affected adhesion capacity of

311 hemocytes, incubated with FSSW or with Vibrio sp. S322. We note the large variations in this

312 parameter (Table 1).

313

\section{3.9. Reactive oxygen species production}

315 Production of reactive oxygen species (ROS) by untreated hemocytes was greatly influenced by

316 oyster phenotype (Table 1) for both hyalinocyte and granulocyte sub-populations (MANOVA,

$317 \mathrm{p}<0.001$ and $\mathrm{p}<0.01$ respectively). ROS production was higher in untreated hemocytes from "S"

318 oysters than in "R" oysters in May and June (Figure 7A and B). There was no diet effect on ROS

319 production of either hemocyte sub-population. The observed, statistically-significant interaction

320 between time and phenotype for granulocyte ROS production indicates that this activity had a

321 different temporal pattern, according to oyster phenotype, during the experiment. 
324 Within the framework of France's national program on oyster summer mortality, MOREST, a

325 family-based genetic experiment was developed to demonstrate that oysters can be selected on

326 their survival. The 'survival' trait was shown to be highly heritable (Dégremont et al., 2007) and

327 the difference in survival between " $R$ " and "S" selected oysters was confirmed over several

328 succesive generations. Although survival performance is highly heritable, the physiological basis

329 of summer-mortality resistance is especially difficult to assess in the field, as all possibly-

330 contributing environmental factors can not be easily and exhaustively measured. Therefore, the

331 present study was undertaken to measure the physiological and survival performances of summer

332 mortality resistant "R" and susceptible "S" oysters under controlled, experimental conditions.

333 Several laboratory experiments indicated that broodstock conditioning over $19^{\circ} \mathrm{C}$ with high food

334 supply often resulted in progressive mortality (Samain, unpubl. oyster-conditioning trials). This

335 mortality was often associated to the presence of Vibrio aestuarianus which has been isolated

336 recurrently from moribund oysters in hatcheries (Garnier et al., in press).

337 In the present study, mortality of three resistant and two susceptible families of second generation

338 G2 was monitored under controlled, experimental conditions with two food rations. Oyster

339 mortality remained low for 2 months (April, May), but then began to rise in June, and then

340 increased rapidly in mid-July when seawater temperature was above $19^{\circ} \mathrm{C}$. As expected, "S"

341 oysters experienced higher mortality than " $R$ " oysters. The difference in mortality rate between

342 "S" and "R"oysters in the present study was in good agreement, although at a lesser extent, with

343 that observed for the same "S" and "R" groups of oysters in field conditions when water

344 temperature reached the same critical threshold, $19^{\circ} \mathrm{C}$ (Soletchnik et al., 2003; Soletchnik et al.,

345 2005). This observation showed thus that survival trait of selected oysters can also be detected

346 under controlled conditions. 
347 Possible relationships between differential survival and physiological parameters (reproduction,

348 energy allocation, immunology) were explored and discussed hereafter.

350 Reproductive parameters and mortality :

351 As previously described (Enriquez-Diaz, 2004; Delaporte et al., 2006a), high trophic condition 352 (12\% of algal dry weight per oyster dry weight) resulted in a higher gonad development than low 353 trophic condition (4\%). Data showed a higher lipid content in "S" oysters compared to "R" 354 oysters, mainly during the first part of vitellogenesis until June. Gonad development estimation 355 using lipid content has been shown several times to be a good indicator of maturation level 356 (Deslous-Paoli et al., 1981; Soletchnik et al., 1999; Soletchnik et al., 2002) and was found to be 357 in good agreement with gonad area estimation using quantitative histological techniques in 358 controlled conditions (Delaporte et al., 2006a). Thus, this result suggests that the gametogenic 359 process may depend upon the oyster phenotype. "S" oysters invested more in reproduction than 360 "R" oysters under the same trophic conditions. Differential reproduction effort could explain, at 361 least partially, the difference in mortality observed not only between "S" and "R" oysters, but 362 also between oysters fed $4 \%$ and $12 \%$ diets. Indeed, experimental infections by $V$. splendidus 363 resulted in a higher mortality in oyster fed the $12 \%$ diet than those fed $4 \%$ (Gay, 2004).

364 The difference of mortality between "R" and "S" oysters accelerated after July at the end of 365 vitellogenesis. During this period, increases in turbidity were observed in the tank by continuous 366 optical records using the MAREL system (Bourles, 2004) that are likely to correspond with 367 gamete emission. These turbidity increases were more frequently observed for "S" oysters fed the $36812 \%$ diet, compared to " $\mathrm{R}$ " oysters fed the same diet (data not shown). These gamete emissions 369 were confirmed in July by the lower condition index and lipid content in "S" oysters compared to 370 "R" oysters when both groups were fed the $12 \%$ diet. However, the CI drop does not correspond 
371 to a massive spawning, but rather to more frequent, partial spawnings in "S" oysters. Thus, when

372 considering the entire gametogenic process, the " $\mathrm{S}$ " oyster families produced a more intense

373 reproductive effort than " $\mathrm{R}$ " oysters, as previously shown for the first generation of selected

374 oysters reared in the field at Fort Espagnol (Morbihan, France) (Enriquez-Diaz, 2004). Partial

375 spawnings were also observed by histological analysis in fully ripe "S" oysters in the field

376 (Enriquez-Diaz, 2004). Thus, it is suggested that high reproductive effort and partial spawnings

377 may contribute to enhancing the susceptibility of "S" oysters to summer mortality and/or

378 infection. It is speculated that spawning events, dependent upon gonad maturity, may provide

379 organic matter in the palleal cavity, thus favoring vibrio proliferation and increasing the infection

380 risk, as shown in experimental trials (F. Le Roux , personal communication).

382 Energetic parameters and mortality:

383 In previous investigations, summer mortality was generally observed in field surveys and

384 laboratory experiments when glycogen content was at its lowest level and oysters were fully 385 ripened (Koganezawa, 1974; Mori, 1979; Perdue et al., 1981). In the present study, glycogen

386 drastically decreased during the gametogenic process, strengthening all previous studies stating 387 that there is a drastic energy consumption during reproductive processes in oysters (Mori et al., 388 1965; Perdue and Erickson, 1984; Ruiz et al., 1992; Berthelin et al., 2000; Delaporte et al., 389 2006a). No relationship, however, could be established between the lowest observed level of 390 glycogen, or the rate of glycogen decrease, and the difference in mortality observed according to

391 food level or oyster phenotype. From this lack of a direct relationship, it appeared that low 392 glycogen only indicates an energy imbalance during gametogenesis, and that energy acquisition 393 during this period depends mostly upon food supply. These data do not, however, provide 394 information on carbohydrate fluxes. Survival differences between oyster phenotypes could, 
395 instead, be related to the mechanisms of energy acquisition and/or expenditure, which may vary

396 in efficiency between "S" and "R" oysters. Indeed, it has been reported that "S" oysters had a

397 lower, compared to "R" oysters, expression of genes coding for glucose $6 \mathrm{P}$ production

398 (Hexokinase, phosphoglucomutase, and phosphoenol-pyruvatecarboxy kinase) in July, just before

399 the mortality event (Samain et al., in press). In Drosophyla melanogaster, a selective mutation in

400 one of the key genes in the energetic pathway can alter flux in the pathway to glycogen synthesis

401 (Verrelli and Eanes, 2000). Polymorphism studies on these genes are ongoing to detect possible

402 detrimental alleles. Other effectors, such as stress (Tanguy et al., 2006) or infection, can lead to

403 similar metabolic pathway perturbation. More work investigating these aspects is needed.

405 Hemocyte parameters and mortality :

406 One of the most striking results in hemocyte parameters was the clear difference between "R" 407 and "S" oysters, in term of reactive oxygen species (ROS) production by untreated hemocytes. In

408 May and June, hyalinocytes and granulocytes of "S" oysters had a much higher ROS production 409 than those of "R" oysters, whatever the dietary treatment. In a previous field study, it was also 410 observed that after 4 months of rearing, 7 months old "S" oysters had a significantly higher ROS

411 production than "R" oysters, whatever the rearing site, Normandy, Brittany or Charentes

412 (Lambert et al., in press). Thus, results obtained for ROS production in experimental conditions

413 with G2 "R" and "S" oysters are in good agreement with those obtained in the field with G1 "R"

414 and "S" oysters. The differences in ROS production observed here in May and June disappeared

415 in July when mortality rate was maximal, suggesting that the high ROS level observed in May-

416 June in "S" oysters may anticipate a major physiological disturbance/stress. In the literature,

417 modulation of ROS production has been associated with various biological events such as acute

418 stress (Lacoste et al., 2002), experimental infection by $V$. aestuarianus (Labreuche et al., 2006b; 
419 Labreuche et al., 2006a) or dietary modification (Hégaret et al., 2004; Delaporte et al., 2006a;

420 Delaporte et al., 2006b) in oysters, but also with changes in metabolic activities associated with 421 detoxification and respiration processes in other biological models (Sheehan and Power, 1999;

422 Batandier et al., 2002; Cardenas et al., 2004; Keller et al., 2004; Manduzio et al., 2005).

423 Moreover, in a review on reproductive strategy and survival (Heininger, 2002), the authors cited

424 several studies suggesting a link between reproduction and oxidative stress. Reproduction

425 increases energy expenditure and nutrient metabolism and results in higher mitochondrial activity 426 and ROS production. Unless the antioxidant defences also increase, reproduction can enhance the

427 susceptibility to oxidative stress. Previous works (Taub et al., 1999) have shown that a mutation 428 of a catalase gene affected life span in the worm Caenorhabditis elegans. According to Heininger

429 (2002) slowed aging in a species is the feature of a better resistance to oxidative stress.

430 According to the above literature, reproductive activity may be considered as a physiological 431 stress. The difference in reproductive activity between " $\mathrm{S}$ " and " $\mathrm{R}$ " oysters may, thus, result in 432 the observed difference in ROS production. In a previous experimental study (Samain et al., in 433 press), "S" oysters, after a 8 days temperature increase from $13^{\circ} \mathrm{C}$ to $19^{\circ} \mathrm{C}$ and high food supply, 434 consistently showed more Hsp 70 (stress related proteins) in gills and lower catalase activities 435 than " $\mathrm{R}$ " oysters, possibly resulting from higher vitellogenic activity in "S" oysters compared to 436 "R" oysters. In another invertebrate model, Landis and Tower (2005) observed that Hsp70 437 expression during aging of Drosophila is up-regulated in response to oxidative stress, obtained 438 for example by null-mutation in either superoxide dismutase (SOD) or catalase gene. Thus, we 439 speculate that temperature and food increase in our experiment led to a higher reproductive 440 activity for "S" oysters, compared to "R", possibly resulting in higher ROS production associated 441 with lower detoxification. We cannot, however, exclude the possibility that selection may have 442 occurred for some enzymes involved in ROS production (NADPH-oxidase, NO synthase) and/or 
443 detoxification (superoxide dismutase, catalase, gluthation peroxidase). With a suppression

444 substractive hybridization experiment ( $\mathrm{SSH}$ ) performed between "R" and " $\mathrm{S}$ " families during a

445 summer mortality event (Huvet et al., 2004), a few of the more-frequently, differentially-

446 expressed genes during several summer mortality events with different age classes of oysters

447 were identified. Among these genes, a cavortin-like gene was shown to be more induced in

448 mantle-gonad tissue from "R" oysters than from " $\mathrm{S}$ " oysters. This gene was later characterized as

449 a hemocyte $C g$ SOD gene (Gonzalez et al., 2005) The expression of this gene is thought to

450 contribute to reactive oxygen species detoxification. These early results suggest that "R" and " $S$ "

451 oysters could possibly be differenciated by antioxidant capacities.

453 Among the other hemocyte parameters, only hyalinocyte counts of "S" oysters were found to

454 increase to a higher level than those of " $R$ " oysters in July, concomitantly with a rise in 455 mortality., Such a significant rapid increase of THC was also observed 3 and 5 days post456 infection in $V$. aestuarianus strain $01 / 32$ injected animals compared to sterile seawater injected 457 animals (Labreuche et al., 2006b). Together $V$. aestuarianus and $V$. splendidus constitute the two 458 major vibrio species found in moribund oysters in the field and are thought to be involved in 459 summer mortality (Lacoste et al., 2001; Gay et al., 2004; Garnier et al., in press). So, the above 460 results tend to support the hypothesis that the difference in mortality measured between the two 461 survival phenotypes in July could possibly result at the end from a differential infection occuring 462 between "R" and "S" oyster.

463

464 In conclusion, the present study showed that parameters associated to reproduction and hemocyte 465 activities can be significantly different in oyster phenotypes " $\mathrm{R}$ " vs " $\mathrm{S}$ " with no or little 466 interaction with food level. During active gametogenesis, "S" oysters developed more lipid 
467 stores, presumably associated with gonad tissue, than "R" oysters. Higher gonad development

468 and partial spawning of " $\mathrm{S}$ " oysters are thought to increase their pathogen and/or mortality 469 susceptibility. Our data confirm and further document the genetic correlation between

470 reproductive effort and survival reported in C. gigas by Ernande et al. (2004).

471 "S" oysters also had hemocytes with significantly-higher ROS production than "R" oysters.

472 Further research is necessary, however, to attribute the change in ROS production to the 473 difference in reproductive activity or differencial gene selection or expression in ROS 474 detoxification-related processes. Although a relationship between hemocyte ROS production and 475 oyster mortality appeared in the present study, it was difficult to establish; nevertheless, 476 numerous examples in literature can be cited where ROS production is related to survival.

477 At the end of the reproductive process, a differential increase of hemocyte number between "R" 478 and "S" oysters may provide a window for infection for a short period of time, as indicated in 479 previous observations during experimental infection studies.

480 Relationships between ROS production, partial spawning, and infection of highly-mature oysters 481 should be continued to be documented. On-going investigations on gene expression, 482 polymorphism of candidate genes and QTL mapping will certainly contribute to better understand 483 the genetic and functional differences between " $S$ " and "R" oysters and, more specifically, the 484 origin of excess ROS production in "S" oysters. Development of infection models and specific 485 probes for pathogen identification in oyster cellular structure are in preparation to better assess 486 the infection dynamics. 
490 We are grateful to technicians from La Tremblade and Bouin for the spat production of the

491 oysters used in the present study and our colleagues of the Argenton hatchery for taking care of

492 oysters during the experimental conditioning. This research was a part of the MOREST project

493 supported by a grant from IFREMER, the Région Bretagne, Région Normandie, Région Pays de

494 Loire, Région Poitou-Charente, the Conseil Général du Calvados and European Community

495 (IFOP). Sincere thanks are due to Gary H. Wikfors for English corrections. Contribution $\mathrm{N}^{\circ} \mathrm{xxx}$

496 of the IUEM, European Institute for Marine Studies (Brest, France)

500 References

501 Auffret, M., Oubella, R., 1995. Cytological and cytometric analysis of bivalve mollusc 502 hemocytes. In: J. S. Stolen TCF, S.A.S., J.T. Zelikoff, S.L. Kaattari, R. S. Anderson, K. Söderhäll, \& B.A. Weeks-Perkins (Ed.), Techniques in Fish Immunology. SOS

Beattie, J.H., Chew, K.K., Hershberger, W.K., 1980. Differential survival of selected strains of Pacific oysters (Crassostrea gigas) during summer mortality. Proc. Nat. Shellfish. Ass.

510 Berthelin, C., Kellner, K., Mathieu, M., 2000. Storage metabolism in the Pacific oyster 511 (Crassostrea gigas) in relation to summer mortalities and reproductive cycle (west coast 512 of France). Comp. Biochem. Phys. B 125, 359-369. 
513 Bligh, E.G., Dyer, W.J., 1959. A rapid method of total lipid extraction and purification. Can. J. $514 \quad$ Biochem. Physiol. 37, 911-917.

515 Bourles, Y., 2004. Ecophysiologie de l'huître creuse : Analyse bioénergétique de la 516 gamétogenèse sous trois conditions trophiques distinctes. DEA Biologie et Productions 517 Animales, Université de Rennes 1.20 p.

518 Cardenas, W., Dankert, J.R., Jenkins, J.A., 2004. Flow cytometric analysis of crayfish 519 haemocytes activated by lipopolysaccharides. Fish Shellfish Immunol. 17, 223-233.

520 Cheney, D.P., MacDonald, B.F., Elston, R.A., 2000. Summer mortality of pacific oysters, Crassostrea gigas (Thunberg): Initial findings on multiple environmental stressors in Puget Sound, Washington, 1998. J. Shellfish Res. 19, 353-359.

523 Cheng, T.C., 1996. Hemocytes: Forms and functions. In: Kennedy, V.S., Newell, R.I.E., Eble, 524 A.F. (Eds.), The Eastern Oyster Crassostrea virginica. Maryland Sea Grant Book, 525 College Park, MD, USA, pp. 299-333.

526 Cheng, T.C., 2000. Cellular Defense Mechanisms in Oysters. In: Fingerman, M., 527 Nagabhushanam, R. (Eds.), Recent Advances in Marine Biotechnology: Immunobiology and Pathology. Sciences Publishers, Inc., Enfield (NH), USA; Plymouth, UK, pp. 43-83.

529 Choquet, G., Soudant, P., Lambert, C., Nicolas, J.-L., Paillard, C., 2003. Reduction of adhesion 530 properties on Ruditapes philippinarum hemocytes exposed to Vibrio tapetis. Dis. Aquat. $531 \quad$ Organ. 57, 109-116.

532 Chu, F.-L.E., 2000. Defense mechanisms of marine bivalves. In: Fingerman, M., 533 Nagabhushanam, R. (Eds.), Recent Advances in Marine Biotechnology: Immunobiology 534 and Pathology. Science publishers, Inc., Enfield (NH), USA; Plymouth, UK, pp. 1-42. 
535 Dégremont, L., 2003. Etude des bases génétiques de la mortalité estivale et des relations avec la croissance chez les juvéniles de l'huître creuse Crassostrea gigas. Phd Thesis. University of Caen (France). 333 pp. (in French).

Dégremont, L., Ernande, B., Bedier, E., Boudry, P., 2007. Summer mortality of hatcheryproduced Pacific oyster spat (Crassostrea gigas). I. Estimation of genetic parameters for survival and growth. Aquaculture 262, 41-53.

Dégremont, L., Boudry, P., Soletchnik, P., Bédier, E., Ropert, M., Huvet, A., Moal, J., Samain, J.F., 2003. Genetic basis of summer mortality in juvenile cupped oysters. (abstract). J. Shellfish Res. 22, 327.

544 Dégremont, L., Bédier, E., Soletchnik, P., Ropert, M., Huvet, A., Moal, J., Samain, J.-F., Boudry, P., 2005. Relative importance of family, site, and field placement timing on survival, growth, and yield of hatchery-produced Pacific oyster spat (Crassostrea gigas). Aquaculture 249, 213-229.

Delaporte, M., Soudant, P., Lambert, C., Moal, J., Pouvreau, S., Samain, J.F., 2006a. Impact of food availability on energy storage and defense related hemocyte parameters of the Pacific oyster Crassostrea gigas during an experimental reproductive cycle. Aquaculture $254,571-582$.

Delaporte, M., Soudant, P., Moal, J., Giudicelli, E., Lambert, C., Séguineau, C., Samain, J.F., 2006b. Impact of 20:4n-6 supplementation on the fatty acid composition and hemocyte parameters of the Pacific oyster Crassostrea gigas. Lipids 41, 567-576.

Delaporte, M., Soudant, P., Moal, J., Lambert, C., Quere, C., Miner, P., Choquet, G., Paillard, C., 558 Samain, J.F., 2003. Effect of a mono-specific algal diet on immune functions in two bivalve species - Crassostrea gigas and Ruditapes philippinarum. J. Exp. Biol. 206, 30533064. 
Deslous-Paoli, J.M., Heral, M., Berthome, J.P., Razet, D., Garnier, J., 1981. Natural reproduction of Crassostrea gigas (Thunberg) in Marennes-Oleron basin in 1979 and 1981: Biochemical and energetic aspects. Rev. Trav. Inst. Peches Marit. Nantes 45, 319-327.

Dubois, M., Gilles, K.A., Hamilton, J.K., Rebers, P.A., Smith, F., 1956. Colorimetric method for determination of sugars and related substances. Anal. Chem. 28, 350-356.

564 Elston, R.A., Beattie, J.H., Friedman, C., Hedrick, R.P., Kent, M.L., 1987. Pathology and significance of fatal inflammatory bacteremia in the Pacific oyster, Crassostrea gigas. J. Fish Dis. 10, 121-132.

Enriquez-Diaz, M., 2004. Variabilité bioénergétique de la reproduction chez l'huître creuse Crassostrea gigas. Phd thesis. Université de Bretagne Occidentale. 193 pp. (in French).

569 Ernande, B., Boudry, P., Clobert, J., Haure, J., 2004. Plasticity in resource allocation based life history traits in the Pacific oyster, Crassostrea gigas. I. Spatial variation in food abundance. J. Evolution. Biol. 17, 342-356.

Evans, S., Langdon C. 2006. Effects of genotypexenvironment interactions on the selection of broadly adapted Pacific oysters (Crassostrea gigas). Aquaculture 261: 522-534.

574 Friedman, C.S., Hedrick, R.P., 1991. Pacific oyster nocardiosis: Isolation of the bacterium and 575 induction of laboratory infections. J. Invertebr. Pathol. 57, 109-120.

576 Gagnaire, B., Soletchnik, P., Madec, P., Geairon, P., Le Moine, O., Renault, T., 2006. Diploid and triploid Pacific oysters, Crassostrea gigas (Thunberg), reared at two heights above and hemocyte parameters. Aquaculture 254, 606-616.

580 Garnier, M., Labreuche, Y., Garcia, C., Robert, M., Nicolas, J.L., in press. Evidence for the 581 involvement of pathogenic bacteria in summer mortalities of the Pacific oyster Crassostrea gigas. Microb. Ecol. 
583 Gay, M., 2004. Infection expérimentale chez Crassostrea gigas: étude de deux souches pathogènes apparentées à Vibrio splendidus. Phd thesis. Université de La Rochelle. 179 pp. (in French).

Gay, M., Renault, T., Pons, A.M., Le Roux, F., 2004. Two vibrio splendidus related strains collaborate to kill Crassostrea gigas: taxonomy and host alterations. Dis. Aquat. Organ. $62,65-74$

Glude, J.B., 1974. A summary report of Pacific coast oyster mortality investigations 1965-1972., Proc. 3rd U.S. Japan Meet. Aquac. Spec. Publ. Fish. Agency, Jap. Gouv.\& Jap. Sea Reg. Fish. Res. Lab. Nigata, Tokyo, pp. 1-28.

Gonzalez, M., Romestand, B., Fievet, J., Huvet, A., Lebart, M.-C., Gueguen, Y., Bachere, E., 2005. Evidence in oyster of a plasma extracellular superoxide dismutase which binds LPS. Biochem. Biophys. Res. Commun. 338, 1089.

Goulletquer, P., Soletchnik, P., Le Moine, O., Razet, D., Geairon, P., Faury, N., Taillade, S., 1998. Summer mortality of the Pacific cupped oyster Crassostrea gigas in the Bay of Marennes-Oléron (France). ICES Statutory Meeting, Population Biology, Mariculture Committee CM 1998 / CC, pp. 14-20.

Hégaret, H., Wikfors, H.G., Soudant, P., Delaporte, M., Alix, J.H., Smith, B.C., Dixon, M.S., Quéré, C., Le Coz, J.R., Paillard, C., Moal, J., Samain, J.F., 2004. Immunological competence of eastern oysters, Crassostrea virginica, fed different microalgal diets and challenged with a temperature elevation. Aquaculture 234, 541-560.

604 Res. Rev. 1, 481-536.

605 Hershberger, W.K., Perdue, J.A., Beattie, J.H., 1984. Genetic selection and systematic breeding 606 in Pacific oyster culture. Aquaculture 39, 237-245. 
607 Huvet, A., Herpin, A., Degremont, L., Labreuche, Y., Samain, J.F., Cunningham, C., 2004. The 608 identification of genes from the oyster Crassostrea gigas that are differentially expressed 609 in progeny exhibiting opposed susceptibility to summer mortality. Gene 343, 211-220.

610 Keller, M., Sommer, A.M., Portner, H.O., Abele, D., 2004. Seasonality of energetic functioning 611 and production of reactive oxygen species by lugworm (Arenicola marina) mitochondria

613 Koganezawa, A., 1974. Present status of studies on the mass mortality of cultured oysters in 614 Japan and its prevention., 3rd U.S. Japan Meet. Aquac. Spec. Publ. Fish. Agency, Jap. 615 Gouv. \& Jap. Sea Reg. Fish. Res. Lab. Nigata, Tokyo, pp. 29-34.

616 Labreuche, Y., Soudant, P., Goncalves, M., Lambert, C., Nicolas, J.L., 2006a. Effects of extracellular products from the pathogenic Vibrio aestuarianus strain $01 / 32$ on lethality and cellular immune responses of the oyster Crassostrea gigas. Dev. Comp. Immunol. 30,

620 Labreuche, Y., Lambert, C., Soudant, P., Boulo, V., Huvet, A., Nicolas, J.L., 2006b. Cellular and 621 molecular hemocyte responses of the Pacific oyster, Crassostrea gigas, following bacterial infection with Vibrio aestuarianus strain 01/32. Microbes Infect. 8, 2715-2724.

625 Lacoste, A., Jalabert, F., Malham, S., Cueff, A., Gelebart, F., Cordevant, C., Lange, M., Poulet, 626 S.A., 2001. A Vibrio splendidus strain is associated with summer mortality of juvenile 627 oysters Crassostrea gigas in the Bay of Morlaix (North Brittany, France). Dis. Aquat. 628 Organ. 46, 139-145. 
629 Lambert, C., Soudant, P., Choquet, G., Paillard, C., 2003. Measurement of Crassostrea gigas 630 hemocyte oxidative metabolism by flow cytometry and the inhibiting capacity of 631 pathogenic vibrios. Fish Shellfish Immunol. 15, 225-240.

632 Lambert, C., Soudant, P., Dégremont, L., Delaporte, M., Moal, J., Boudry, P., Jean, F., Huvet, A., 633 Samain, J.-F., in press. Hemocyte characteristics in families of oysters, Crassostrea gigas, selected for differential survival during summer and reared in three sites. Aquaculture in press.

636 Landis, G.N., Tower, J., 2005. Superoxide dismutase evolution and life span regulation. Mech. Ageing. Dev. 126, 365-379.

638 Langdon, C., Evans, F., Jacobson, D., Blouin, M., 2003. Yields of cultured Pacific oysters 639 Crassostrea gigas Thunberg improved after one generation of selection. Aquaculture 220, 640 227-244.

641 Le Roux, F., Gay, M., Lambert, C., Waechter, M., Poubalanne, S., Chollet, B., Nicolas, J.L., 642 Berthe, F., 2002. Comparative analysis of Vibrio splendidus-related strains isolated during 643 Crassostrea gigas mortality events. Aquat. Living Resour. 15, 251-258.

644 Lipovsky, V.P., Chew, K.K., 1972. Mortality of Pacific oysters Crassostrea gigas: the influence 645 of temperature and enriched seawater on survival. Proc. Nat. Shellfish. Ass. 62, 72-82.

646 Manduzio, H., Rocher, B., Durand, F., Galap, C., Leboulenger, F., 2005. The point about 647 oxidative stress in molluscs. I.S.J. 2, 91-104.

648 Marie, D., Partensky, F., Vaulot, D., Brussaard, C.P.D., 1999. Enumeration of phytoplankton, 649 bacteria, and viruses in marine samples. In: Robinson, J.P., Darzynkiewicz, Z., Dean, 650 P.N., Orfao, A., Rabinovitch, P., Stewart, C., Tanke, H.J., Wheeless, L. (Eds.), Current 651 protocols in cytometry. John Wiley \& Sons, Inc., New York. N.Y., pp. 11.11.11-11.11.15. 
652 Mori, K., 1979. Effects of artificial eutrophication on the metabolism of the Japanese Oyster 653 Crassostrea gigas. Mar. Biol. 53, 361-369.

654 Mori, K., Tamate, H., Imai, T., Itikawa, O., 1965. Changes in the metabolism of lipids and 655 glycogen of the oyster during the stages of sexual maturation and spawning. Bull. Tohoku 656 Reg. Fish. Res. Lab. 25, 65-88.

657 Nicolas, J.L., Corre, S., Gauthier, G., Robert, R., Ansquer, D., 1996. Bacterial problems associated with scallop (Pecten maximus) larval culture. Dis. Aquat. Organ. 27, 67-76.

Perdue, J., A., Beattie, J., H., Chew, K., K., 1981. Some relationships between gametogenic cycle and summer mortality phenomenon in the Pacific oyster (Crassostrea gigas) in Washington state. J. Shellfish Res. 1, 9-16.

662 Perdue, J.A., Erickson, G., 1984. A comparison of the gametogenic cycle between the Pacific 663 oyster Crassostrea gigas and the Suminoe oyster Crassostrea rivularis in Washington State. Aquaculture 37, 231.

665 Pipe, R.K., 1992. Generation of reactive oxygen metabolites by the haemocytes of the mussel 666 Mytilus edulis. Dev. Comp. Immunol. 16, 111-122.

667 Ruiz, C., Abad, M., Sedano, F., Garcia-Martin, L.O., Lopez, J.L.S., 1992. Influence of seasonal 668 environmental changes on the gamete production and biochemical composition of Crassostrea gigas (Thunberg) in suspended culture in El Grove, Galicia, Spain. J. Exp. Mar. Biol. Ecol. 155, 249.

671 Samain, J.F., Dégremont, L., Soletchnik, P., Haure, J., Bédier, E., Ropert, M., Moal, J., Huvet, 672 A., Bacca, H., Van Wormhoudt, A., Delaporte, M., Costil, K., Pouvreau, S., Lambert, C., 673 Boulo, V., Soudant, P., Nicolas, J.L., Le Roux, F., Renault, T., Gagnaire, B., Geret, F., 674 Boutet, I., Burgeot, T., Boudry, P., in press. Genetically based resistance to summer 
mortality in the Pacific oyster (Crassostrea gigas) and its relationship with physiological, 676 immunological characteristics and infection processes. Aquaculture in press.

677 Sheehan, D., Power, A., 1999. Effect of seasonality on xenobiotic and antioxidant defence 678 mechanisms of bivalve molluscs. Comp. Biochem. Phys. C 123, 193-199.

679 Soletchnik, P., Lambert, C., Costil, K., 2005. Summer mortality of Crassostrea gigas (Thunberg) 680 in relation to environmental rearing conditions. J. Shellfish Res. 24, 197-207.

681 Soletchnik, P., Le Moine, O., Faury, N., Razet, D., Geairon, P., Goulletquer, P., 1999. Mortalité 682 de l'huître Creuse Crassostrea gigas dans le bassin de Marennes-Oléron: Etude de la variabilité spatiale de son environnement et de sa biologie par un système d'informations géographiques (SIG). Aquat. Living Resour. 12, 131-143.

Soletchnik, P., Huvet, A., Le Moine, O., Razet, D., Geairon, P., Faury, N., Goulletquer, P., 686 Boudry, P., 2002. A comparative field study of growth, survival and reproduction of Crassostrea gigas, C. angulata and their hybrids. Aquat. Living Resour. 15, 243.

Soletchnik, P., Ropert, M., Huvet, A., Moal, J., Degrémont, L., Bedier, E., Bouget, M., Dubois, 690 B., Martin, J.L., Enriquez Diaz, M., Faury, N., Le Moine, O., Renault, T., Gagnaire, B., Samain, J.F., 2003. Characterization of summer mortalities of Crassostrea gigas oyster in France in relation to environmental parameters (abstract). J. Shellfish Res. 22, 354.

692 Tanguy, A., Boutet, I., Boudry, P., Degremont, L., Laroche, J., Moraga, D., 2006. Molecular 693 identification and expression of the phosphoglucomutase (PGM) gene from the Pacific

695 Taub, J., Lau, J.F., Ma, C., Hahn, J.H., Hoque, R., Rothblatt, J., Chalfie, M., 1999. A cytosolic 696 catalase is needed to extend adult lifespan in C. elegans daf-C and clk-1 mutants. Nature 697 $399,162-166$. 
698 Verrelli, B.C., Eanes, W.F., 2000. Extensive amino acid polymorphism at the pgm locus is 699 consistent with adaptive protein evolution in Drosophila melanogaster. genetics 156, 700 1737-1752.

701 Volety, A.K., Chu, F.L., 1995. Suppression of chemiluminescence of eastern oyster (Crassostrea 702 virginica) hemocytes by the protozoan parasite Perkinsus marinus. Dev. Comp. Immunol. $703 \quad 19,135-142$.

704 Waechter, M., Le Roux, F., Nicolas, J.L., Marissal, E., Berthe, F., 2002. Characterization of 705 pathogenic bacteria of the cupped oyster Crassostrea gigas. C. R. Biologies 325, 231-238.

706 Walne, P.R., Mann, R., 1975. Growth and biochemical composition in Ostrea edulis and 707 Crassostrea gigas. In: Barnes, H. (Ed.), Ninth European Marine Biology Symposium, pp. $708 \quad 587-607$. 
711 Table 1: Summary of the three-way analysis of variance comparing biochemical and hemocyte parameters (independent variables) 712 according to diet, phenotype (resistant $\mathrm{R}$ and susceptible $\mathrm{S}$ ), and sampling date and their interactions during the experiment. *: $\mathrm{p}<0.05$; $713 * *: \mathrm{p}<0.01 ; * * *: \mathrm{p}<0.001 ; * * * *: \mathrm{p}<0.0001 ;$ NS: non significant.

\begin{tabular}{|c|c|c|c|c|c|c|c|c|c|}
\hline \multirow{3}{*}{$\begin{array}{l}\text { Variables } \\
\text { Condition index }\end{array}$} & \multicolumn{5}{|c|}{ Main effects } & \multicolumn{4}{|c|}{ Interactions } \\
\hline & \multirow{2}{*}{$\begin{array}{l}\begin{array}{l}\text { Time } \\
\text { effect }\end{array} \\
\text { NS }\end{array}$} & \multicolumn{2}{|c|}{ Diet effect } & \multicolumn{2}{|c|}{ Phenotype effect } & \multirow{2}{*}{$\begin{array}{l}\text { Time vs } \\
\text { Diet } \\
*\end{array}$} & \multirow{2}{*}{$\begin{array}{l}\text { Time vs } \\
\text { Phenotype } \\
\text { ** }\end{array}$} & \multirow{2}{*}{$\begin{array}{l}\text { Diet vs } \\
\text { Phenotype }\end{array}$} & \multirow{2}{*}{$\begin{array}{l}\text { Time vs Diet } \\
\text { vs Phenotype } \\
\text { NS }\end{array}$} \\
\hline & & $* * * *$ & $12 \%>4 \%$ & NS & - & & & & \\
\hline Carbohydrates (mg/g DW) & $* * * *$ & $*$ & $12 \%>4 \%$ & $*$ & $\mathrm{~S}>\mathrm{R}$ & $*$ & NS & NS & NS \\
\hline Lipids (mg/g DW) & $*$ & $* * * *$ & $12 \%>4 \%$ & $* *$ & $\mathrm{~S}>\mathrm{R}$ & NS & $* * *$ & NS & NS \\
\hline Hemocyte counts (cells/ml) & $* * * *$ & NS & - & NS & - & NS & NS & NS & NS \\
\hline Hyalinocyte counts (cells/ml) & $* * * *$ & $*$ & $12 \%>4 \%$ & $*$ & $\mathrm{~S}>\mathrm{R}$ & NS & NS & NS & NS \\
\hline Granulocyte counts (cells/ml) & $* * *$ & NS & - & NS & - & NS & NS & NS & NS \\
\hline Hemocyte mortality (\%) & $* * * *$ & NS & - & NS & - & NS & NS & NS & NS \\
\hline Phagocytosis (\%) & $* * * *$ & NS & - & NS & - & NS & NS & NS & NS \\
\hline Adhesion (\%, with FSSW) & $* *$ & NS & - & NS & - & NS & NS & NS & NS \\
\hline Adhesion (\%, with Vibrio S322) & $* * *$ & NS & - & NS & - & $*$ & NS & NS & NS \\
\hline ROS production in hyalinocytes & NS & NS & - & $* * *$ & $\mathrm{~S}>\mathrm{R}$ & NS & NS & NS & NS \\
\hline ROS production in granulocytes & $*$ & NS & - & $* *$ & $\mathrm{~S}>\mathrm{R}$ & NS & $*$ & NS & NS \\
\hline
\end{tabular}


718 Fig. 1: Cumulative mortality percentages of susceptible " $S$ " and resistant "R" oysters fed the 4 719 and $12 \%$ diets.

720 Fig. 2 : Condition index of susceptible "S" and resistant "R" oyster families fed two dietary

721 rations (4 or 12\% of algal dry weight/ oyster dry weight, daily) under controlled conditions

722 (Mean \pm S.D., $\mathrm{n}=10$ ). Condition index of oysters fed the12\% ration was significantly higher than

723 that of oysters fed the $4 \%$ ration $(\mathrm{P}<0.001)$. There was no significant effect of sampling date or

724 phenotype.

725 Fig. 3: Carbohydrate (A) and lipid (B) contents of susceptible "S" and resistant "R" oyster

726 families fed two dietary rations (4 or 12\% of algal dry weight/ oyster dry weight, daily) under

727 controlled conditions. Results are expressed as mg carbohydrates (A) and total lipids (B) per mg

728 oyster dry weight (Mean \pm S.D., $n=10)$. Carbohydrate and lipid contents were significantly higher

729 in oyster fed the 12 diet than those fed the $4 \% \operatorname{diet}(\mathrm{P}<0.05$ and $\mathrm{P}<0.001$, respectively).

730 Carbohydrate and lipid contents of susceptible "S" oyster families were significantly higher than

731 those of resistant " $\mathrm{R}$ " oyster families $(\mathrm{P}<0.05$ and $\mathrm{P}<0.01$, respectively).

732 Fig. 4: Granulocyte (A) and hyalinocyte (B) concentrations of susceptible "S" and resistant "R"

733 oyster families reared under controlled conditions, regardless of the dietary rations. Results are

734 expressed as cells $\mathrm{ml}^{-1}$ (Mean \pm S.D., $\mathrm{n}=2$ 20. Hyalinocyte concentration is significantly higher in

735 "S" oysters than in "R" oysters.

736 Fig. 5: Phagocytic activity of hemocytes from susceptible "S" and resistant "R" oyster families

737 reared under controlled conditions, regardless of the dietary rations. Results are expressed as

738 percentage of hemocytes that have engulfed three beads and more (Mean \pm S.D., $n=6$ ).

739 Fig. 6A and 6B: Adhesion of hemocytes incubated with filtered sterile seawater, FSSW (A) and

740 with Vibrio sp. S322 at 50 cells per hemocyte (B). Hemocytes were sampled from susceptible "S" 
741 and resistant " $R$ " oyster families reared under controlled conditions, regardless of the dietary

742 rations. Results are expressed in percentage of adhering cells (Mean \pm S.D., $n=6$.

743 Fig. 7A and 7B: Granulocyte(A) and hyalinocyte(B) ROS production of hemocytes from

744 susceptible " $\mathrm{S}$ " and resistant " $\mathrm{R}$ " oyster families reared under controlled conditions, regardless of

745 the dietary rations. Results are presented as the mean DCF fluorescence (quantitatively related to

746 ROS production) expressed in arbitrary units, AU (Mean \pm S.D., n=6). 


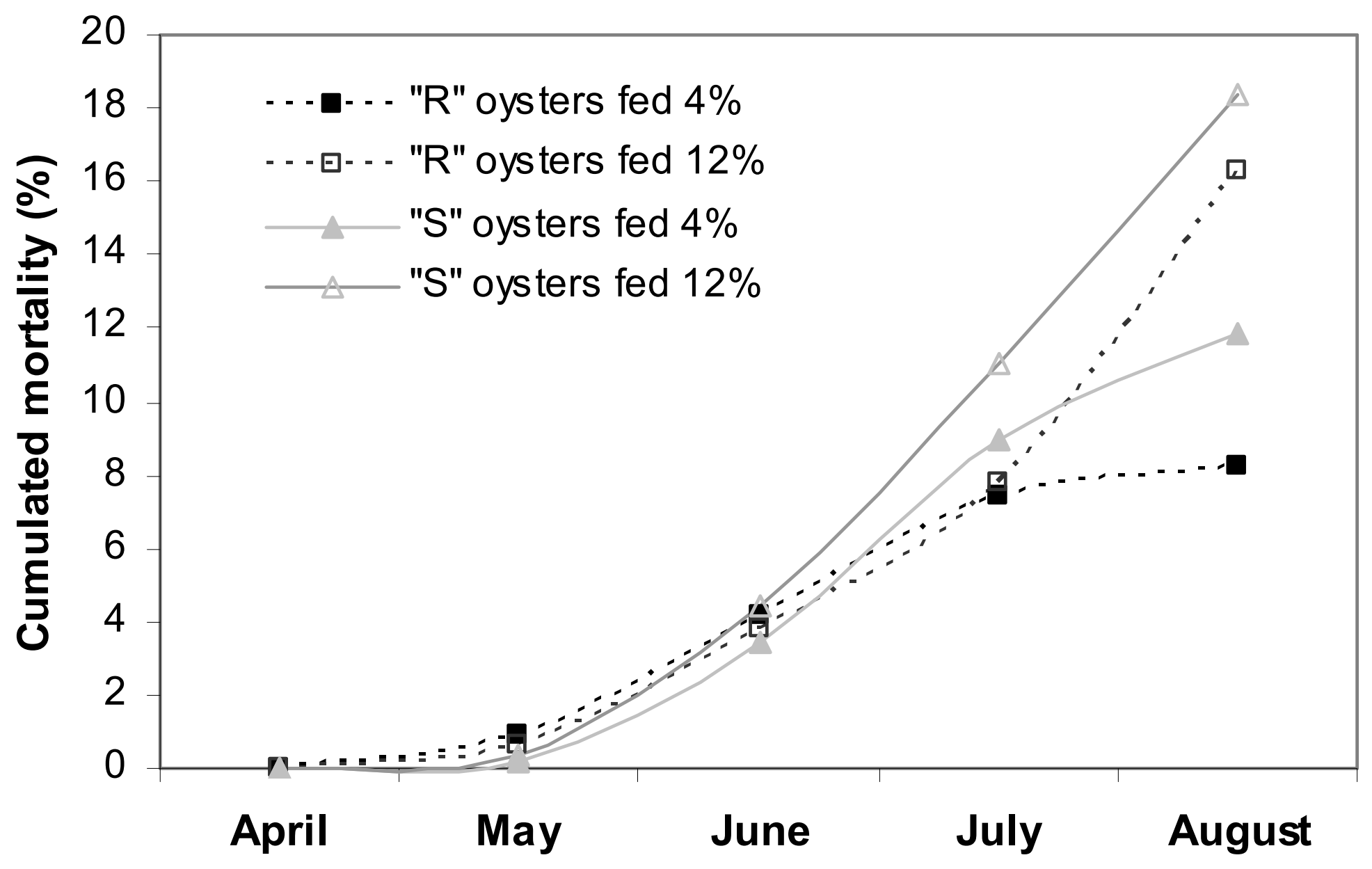

$749 \quad$ Figure 1 


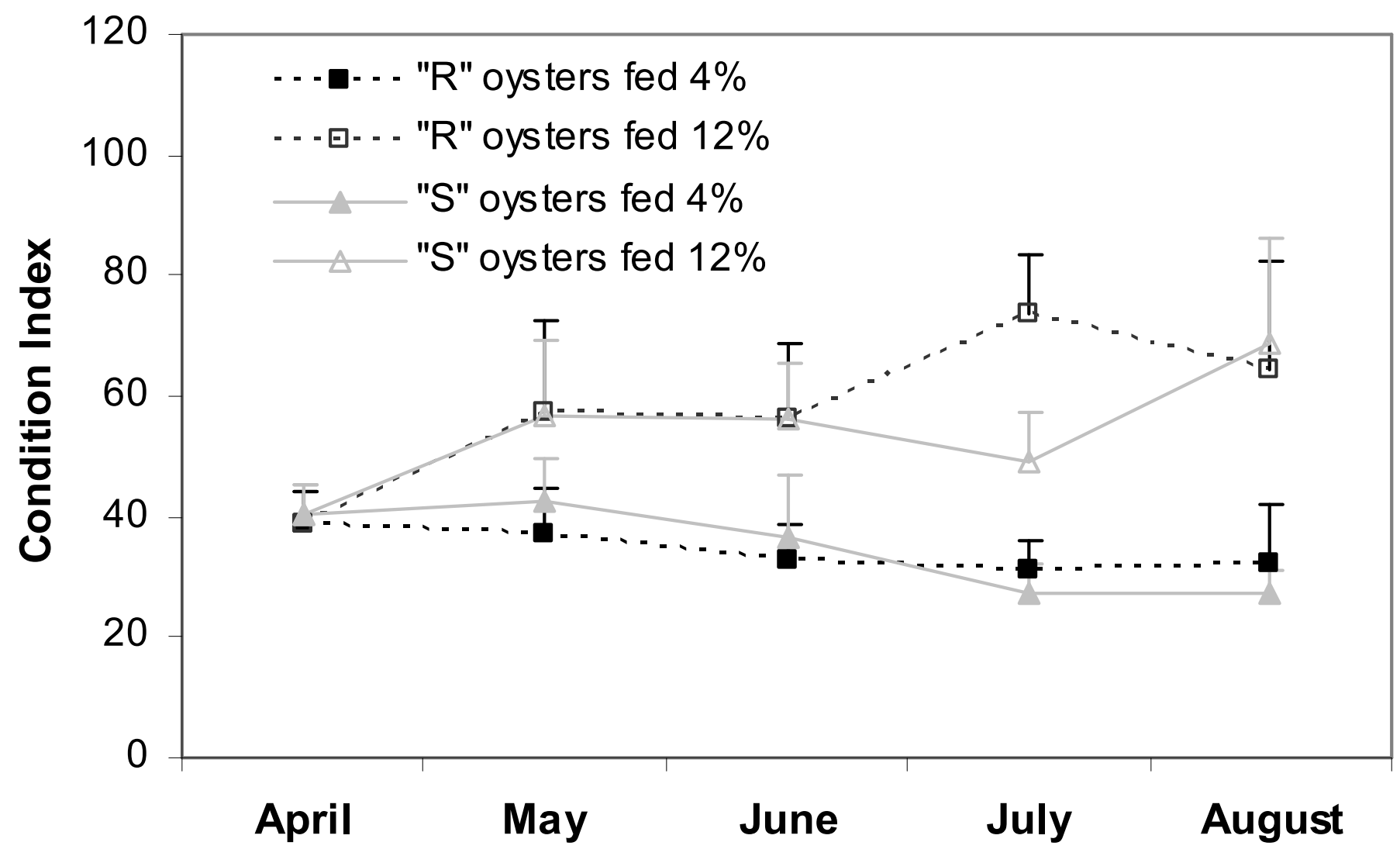


755

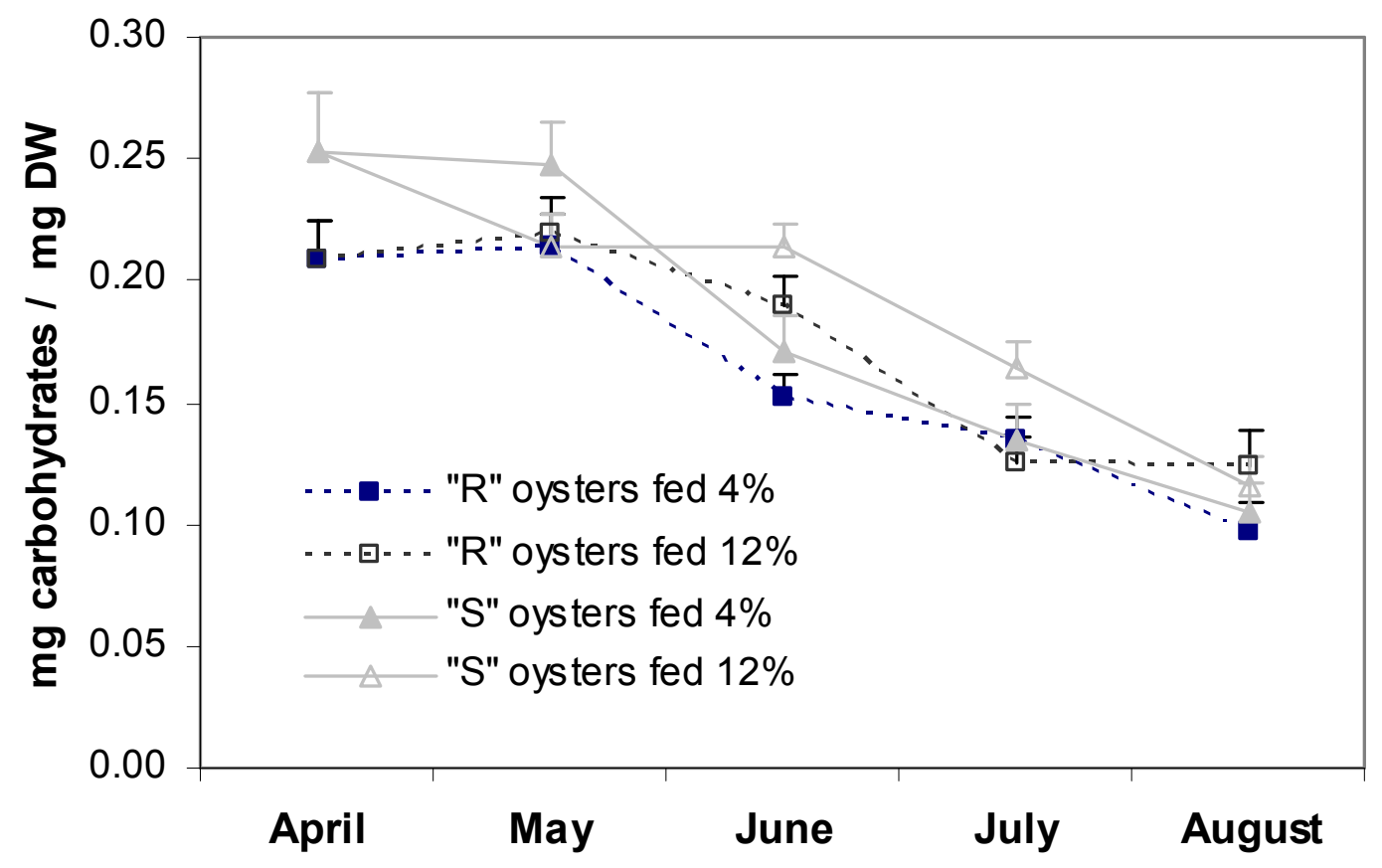

756 B

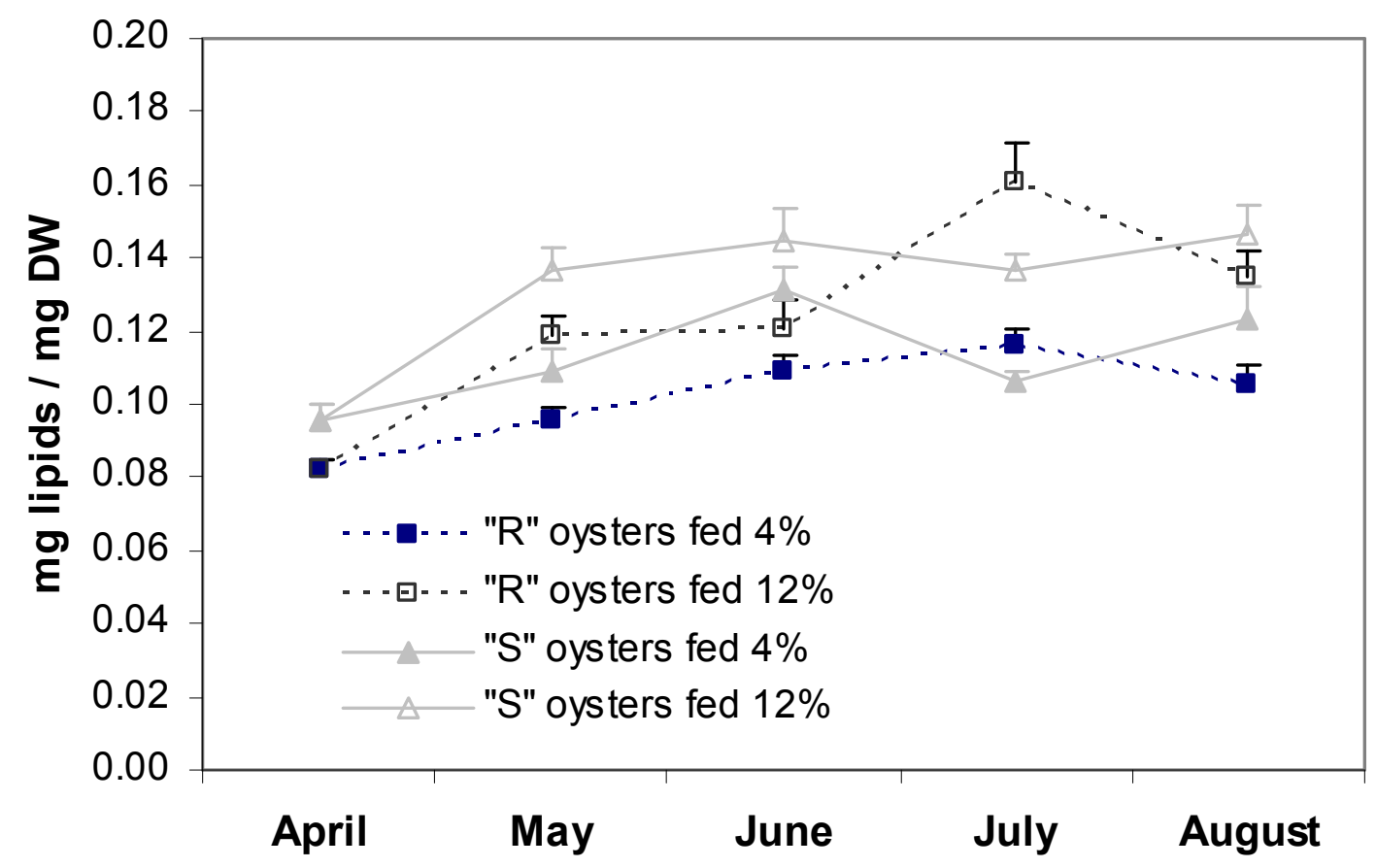

Figure $3 A$ and 3B 
760

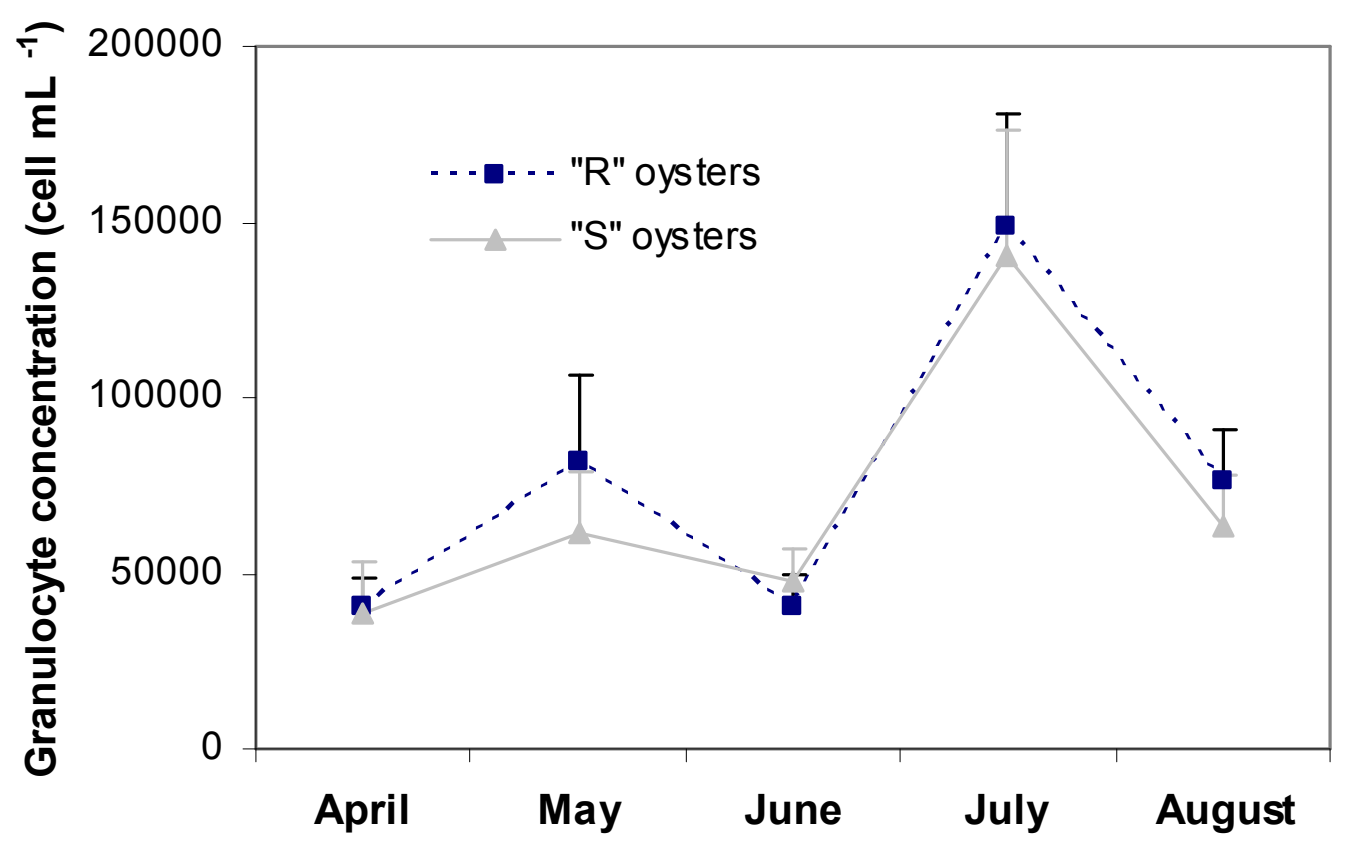

761 B

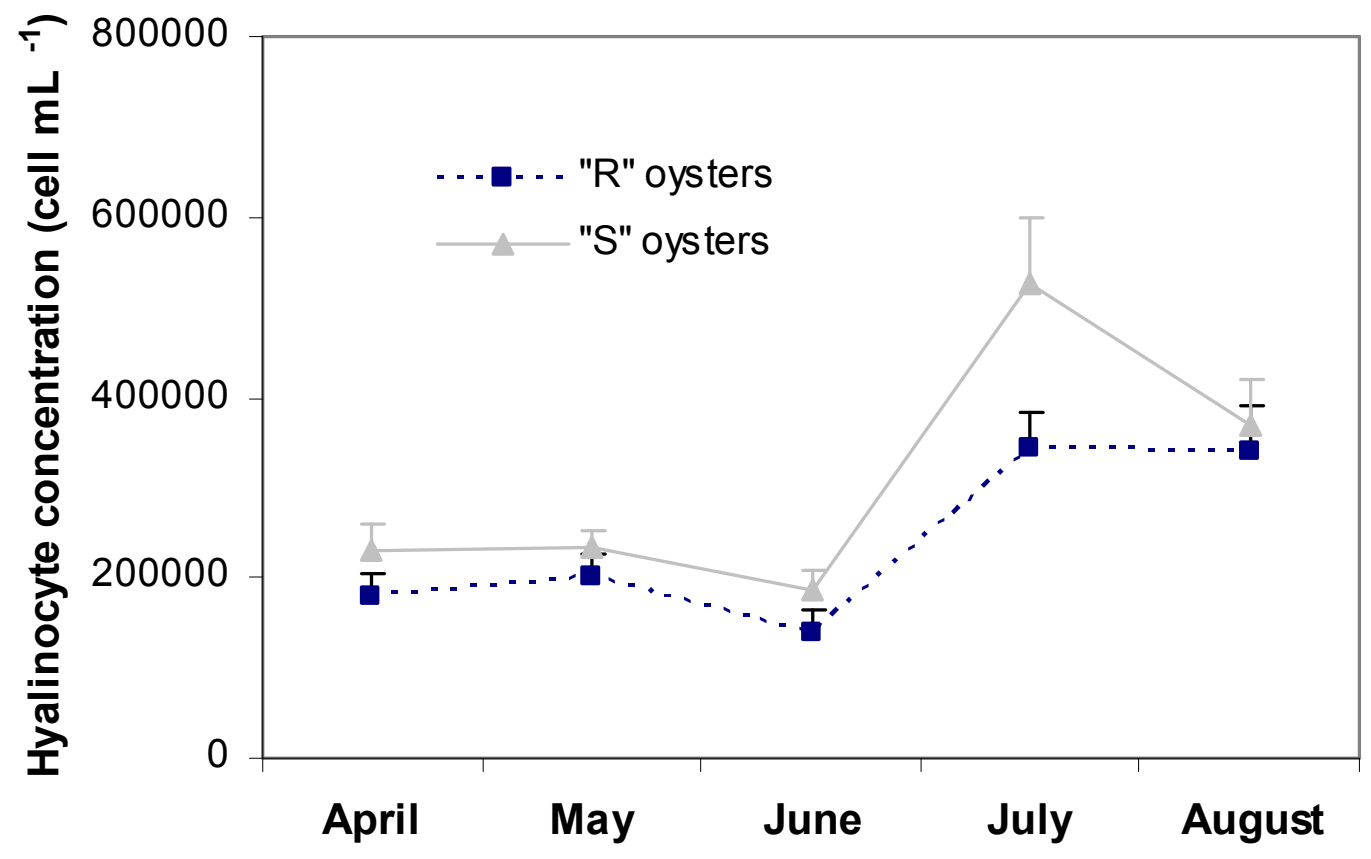

763 Figure 4A and 4B 


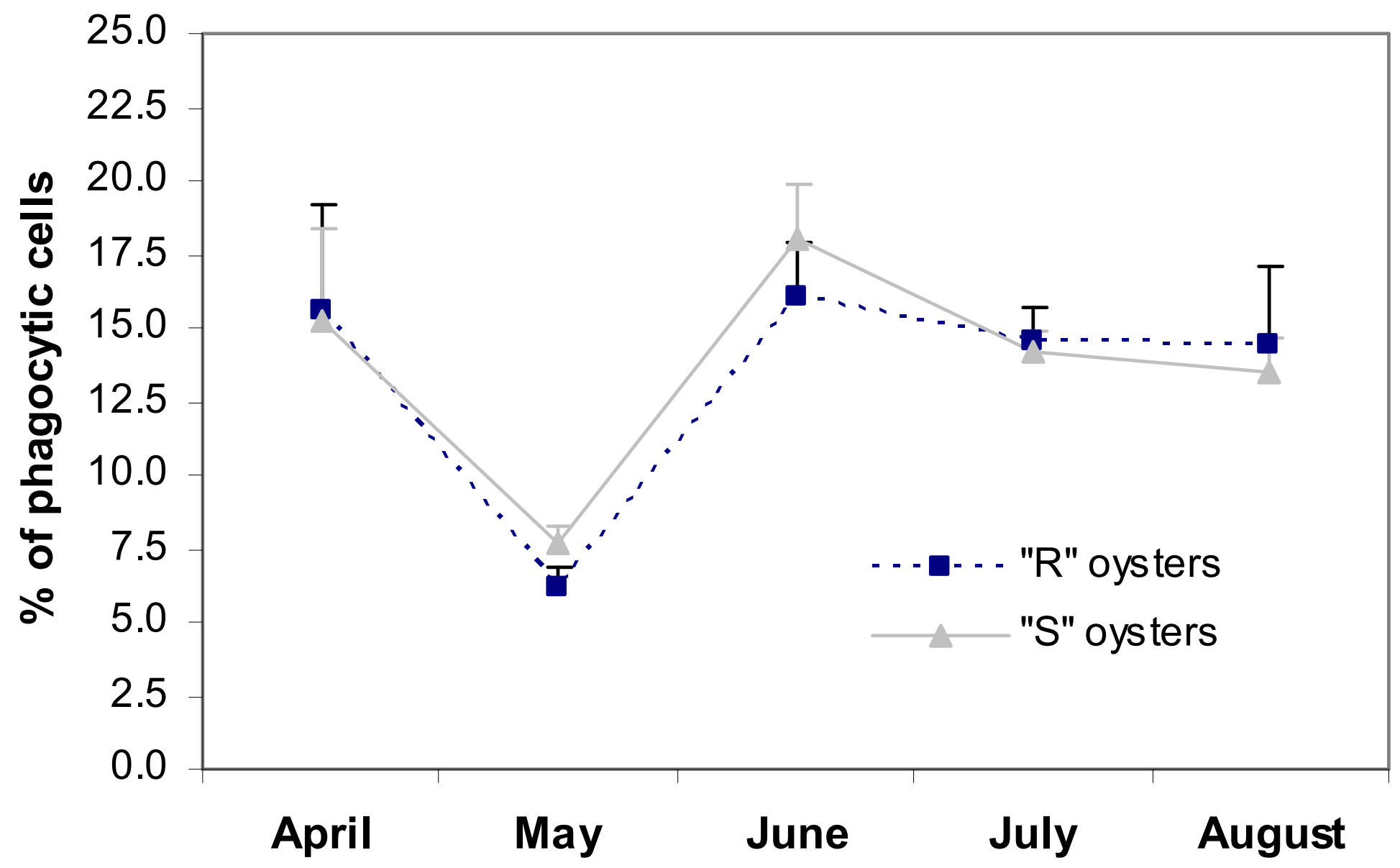


768

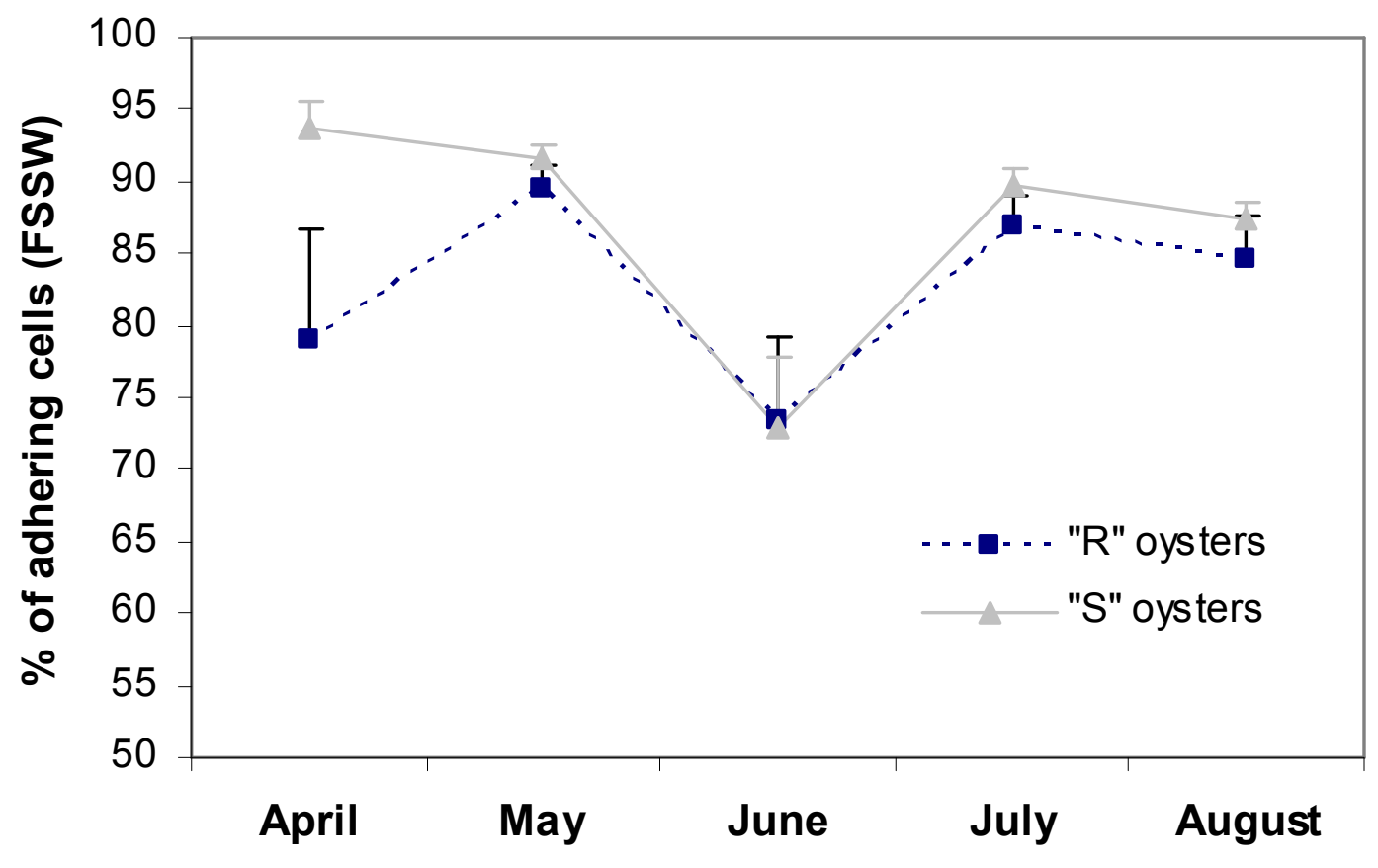

769 B

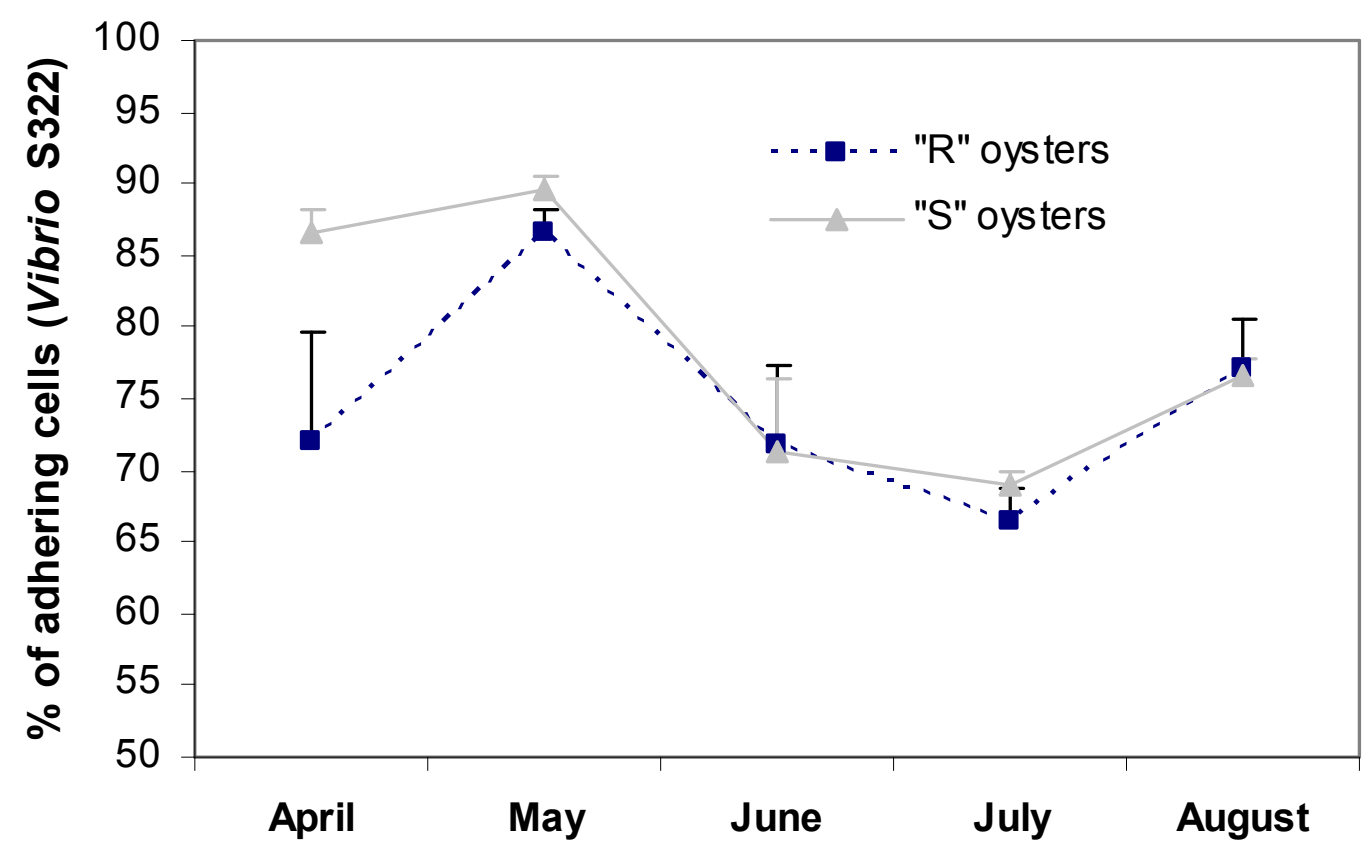

771 Figure 6A and 6B 


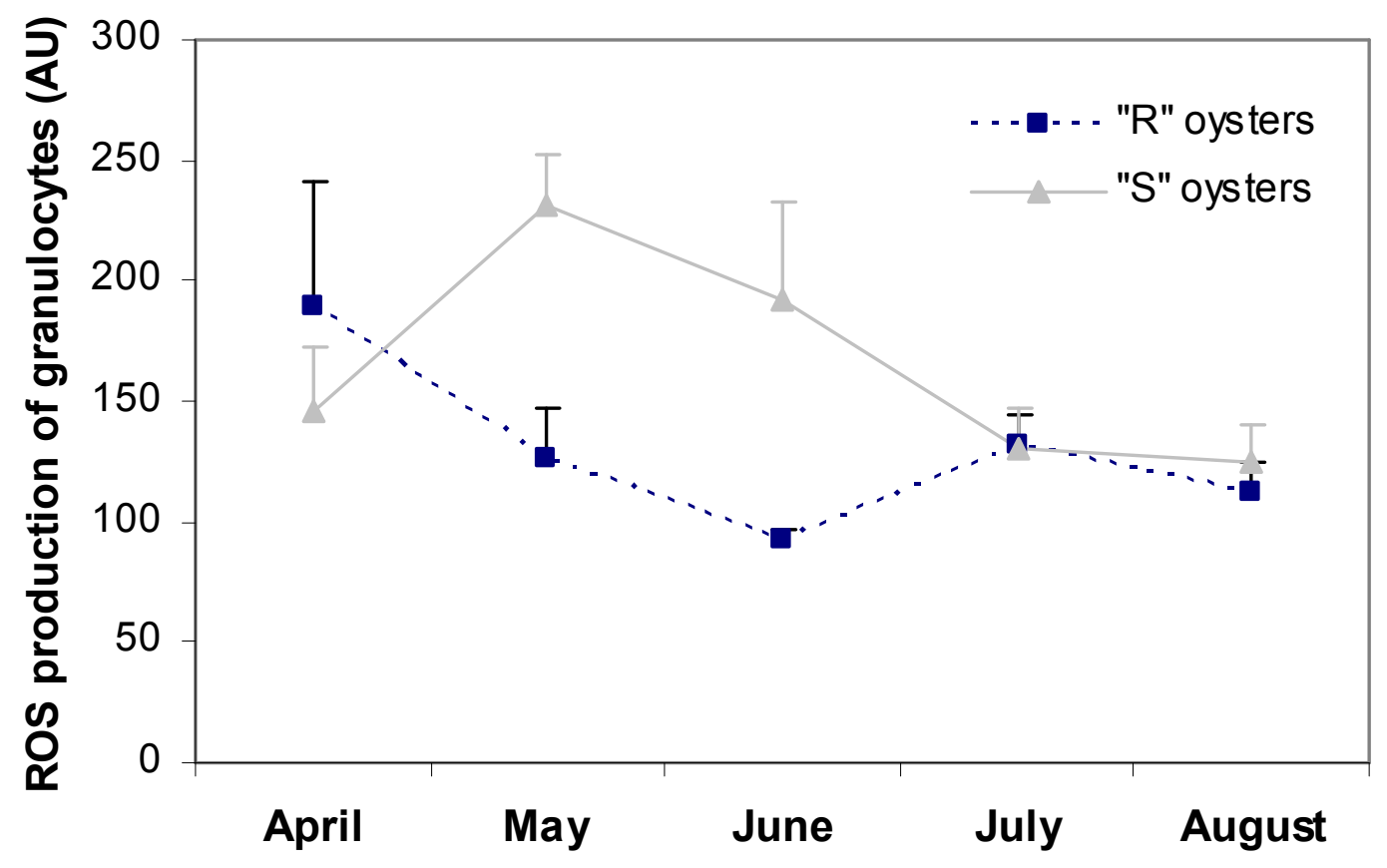

774 B

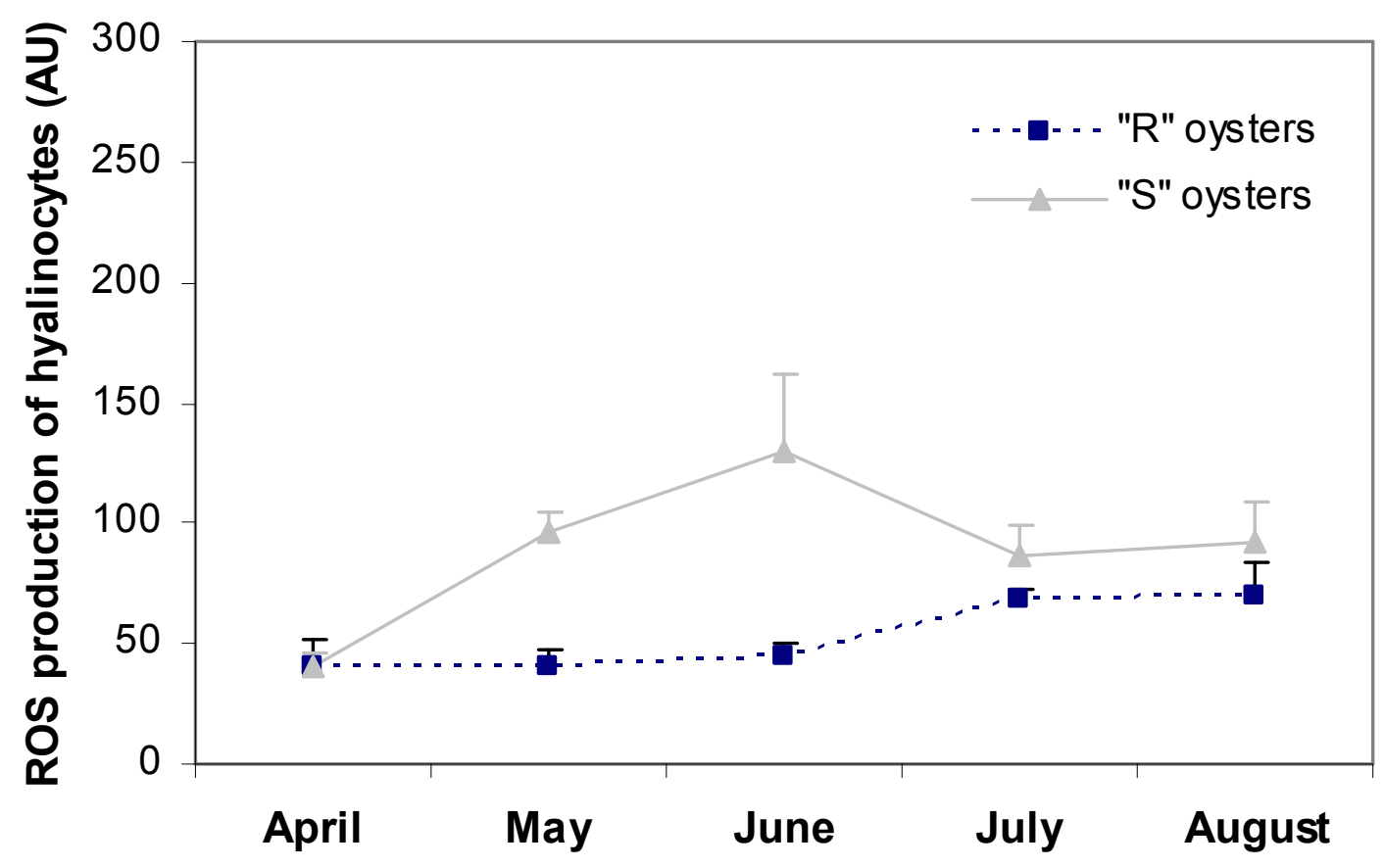

$776 \quad$ Figure 7A and 7B 